\title{
HENKILÖSTÖN LUOTTAMUS ORGANISAATIOON JA JOHTAJIIN SOSIAALI- JA TERVEYSPALVELUJEN ORGANISAATIOMUUTOKSESSA
} \author{
Laura Hietapakka: VTM, tutkija, Terveyden ja byvinvoinnin laitos \\ Sanna Laulainen: YTT, professori (ma.), Itä-Suomen yliopisto \\ Vuokko Niiranen: YTT, HTL, professori, Itä-Suomen yliopisto \\ Timo Sinervo: VTT, tutkimusprofessori, Terveyden ja byvinvoinnin laitos \\ joakim.zitting@diak.fi; laura.bietapakka@thl.fi; sanna.laulainen@uef.fi; \\ vuoke.noniiranen@uef.fi; timo.sinervo@thl.fi \\ Janus vol. 28 (2) 2020, 168-184
}

Joakim Zitting: YTM, projektitutkija, Itä-Suomen yliopisto/ tutkija, Diakonia-ammattikorkeakoulu

Tiivistelmä

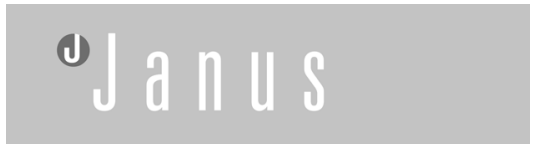

$\mathbf{y}$ VERTAISARVIOITU
KOLEGALLT GRANSKA

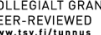

Artikkelissa tarkastellaan luottamusta kontekstina laaja organisaatiomuutos, jossa usean kunnan sosiaali- ja terveyspalvelut yhdistettiin kuntayhtymäksi. Haastatteluaineisto kerättiin eri tasojen johtajilta sekä työntekijöiltä eri toimialoilta ja analysoitiin sisällönanalyysillä. Johtajiin sekä organisaatioon kohdistuneen luottamuksen muutosta tarkasteltiin luotettavuuden osatekijöillä, jotka vaikuttavat luottamuksen syntyyn. Luottamus sujuvoittaa yhdessä työskentelyä, edistää työtyytyväisyyttä ja edesauttaa organisaatiomuutoksen onnistumista, joten organisaatioissa kannattaa kiinnittää siihen huomiota. Muutokset johtamis- ja organisaatiorakenteessa, toimintakulttuurissa sekä osallisuuden kokemuksissa heikensivät johtajien ja uuden organisaation kokemista luotettavana. Muun muassa kuntayhtymän kehittämisen terveydenhoitokeskeisyys vaikutti tähän. Vastaavanlaisissa muutoksissa kannattaa kiinnittää enemmän huomiota muutosviestintään, työntekijöiden ja johtajien tukemiseen sekä työntekijöiden ja eri johtotasojen väliseen vuorovaikutukseen.

\section{JOHDANTO}

Luottamuksen on sanottu olevan "ensimmäinen sääntö”, josta voi johtaa perusteet ihmisten kanssakäymiselle ja muulle inhimilliselle toiminnalle. Esimerkiksi raha, laki, johtamisopit ja erilaiset yhteiskunnalliset järjestelmät sekä instituutiot tarvitsevat luottamusta säilyttääkseen toimintakykynsä. (Harisalo \& Miettinen 2012.) Luottamuksen merkitys näkyy myös johtamis- ja organisaatiotutkimuksessa, jossa luottamusta on tutkittu paljon. Tämän taustalla on ollut muun muassa perinteisten hierarkioiden madaltuminen ja erilaisten kontrollimekanismien vähentyminen, jolloin työntekijöiden rooli sekä vastuut kasvavat ja luottamuksen merkitys korostuu. Myös moniammatillisten itseohjautuvien tiimien ja organisaatiosekä professiorajat ylittävän yhteistyön yleistyminen ovat vaikuttaneet luottamuksen merkityksen kasvuun. (Mayer ym. 1995, 710; Six 2005, 1-2; Connell \& Mannion 2006.)

Luottamustutkimusten kohteena ovat olleet muun muassa organisaatioiden keskinäinen luottamus sekä organisaatioiden sisäinen luottamus, kuten kollegoiden luottamus toisiinsa ja johtajien sekä työntekijöiden välinen luottamus. Myös työntekijöiden luottamus organisaatiota kohtaan on ollut kiinnostuksen kohteena. (Dietz \& den Hartog 2006; Vanhala 2011; Fulmer \& Gelfand 2012.) Luottamuksen on todettu olevan organisaatioille tärkeää monin ta- 
voin. Se esimerkiksi mahdollistaa yhteistoiminnallisen työskentelyn, edistää monia työtyytyväisyyden ulottuvuuksia ja organisaatioon sitoutumista, helpottaa verkostosuhteiden ja tilapäisten työryhmien luomista sekä edistää organisaatiomuutosten onnistumista muun muassa luomalla turvallisuudentunnetta ja edistämällä riskien ottamista. (Rousseau ym. 1998, 394; Dirks \& Ferrin 2002; Six 2005, 1-2; Fulmer \& Gelfand 2012.)

Luottamuksen tärkeys organisaatiomuutoksille tuo ajankohtaisen näkökulman luottamuksen laajemmalle tarkastelulle ja sitä koskevalle tutkimukselle. Tässä artikkelissa tarkastellaan laajan haastatteluaineiston avulla johtajiin ja organisaatioon kohdistuvaa luottamusta sosiaali- ja terveyspalvelujen organisaatiomuutoksessa. Kyseessä on laaja organisaatiomuutos, jossa usean kunnan sosiaali- ja terveyspalvelut sekä erikoissairaanhoito on yhdistetty suureksi kuntayhtymäksi. Tällaisessa muutoksessa kohtaavat paitsi kuntakohtaiset toimintakulttuurit myös erilaiset ammatilliset kulttuurit, kuten sosiaalipalvelujen ja terveyspalvelujen toimintakulttuurit ja perinteet (esim. Taskinen 2005).

Yhteiskunnallisessa keskustelussa on viime vuosina käsitelty sosiaali- ja terveyspalvelujen integraatiota. Huolta on herättänyt muun muassa sosiaalipalvelujen asema integraatiossa, professioiden väliset rajat sekä hallinnollisen integraation eteneminen käytäntöön asti. (Esim. Hiilamo 2015; Kröger 2017.) Sosiaali- ja terveyspalveluja integroivia organisaatioita tullaan todennäköisesti muodostamaan lisää tulevaisuudessa, ja näissä organisaatiomuutoksissa on tar- vetta luottamukselle. Tämän artikkelin tarkoituksena on lisätä ymmärrystä siitä, mitä luottamukselle tapahtuu sosiaali- ja terveyspalvelujen organisaatiomuutoksessa ja auttaa tunnistamaan ja huomioimaan luottamukseen vaikuttavia tekijöitä tulevissa organisaatiouudistuksissa ja -muutoksissa ${ }^{1}$.

Artikkeli pyrkii myös täydentämään kotimaista luottamustutkimusta, jossa luottamusta on tarkasteltu etenkin terveyspalvelujen kontekstissa (esim. Ruokamo ym. 2012; Hämäläinen ym. 2014; Kangas 2017), muttei kovinkaan paljoa yhdistetyissä sosiaali- ja terveyspalveluissa. Niiden osalta luottamusta on käsitelty yhdessä hankkeessa henkilöstön innovatiivisuuden näkökulmasta (esim. Sinervo ym. 2015). Artikkelin tutkimuskysymyksinä ovat:

Miten luottamus johtajiin on muuttunut sosiaali- ja terveyspalvelujen organisaatiomuutoksessa?

Miten luottamus organisaatioon on muuttunut sosiaali- ja terveyspalvelujen organisaatiomuutoksessa?

\section{LUOTTAMUS MUUTTUVISSA ORGANISAATIOISSA}

Luottamus on moniulotteinen käsite, jota eri tieteenalat ovat määritelleet ja tutkineet eri näkökulmista (Dietz \& den Hartog 2006, 558). Organisaatiotutkimuksissa yleisesti esiintyvän määritelmän mukaan luottamuksella tarkoitetaan jonkin osapuolen halukkuutta olla havoittuvainen toisen osapuolen toimille. Tämä halukkuus pohjautuu odotukselle siitä, että toinen osapuoli toimii luottavalle osapuolelle tärkeällä 
tavalla riippumatta siitä, onko luottajalla mahdollisuutta kontrolloida tai tarkkailla luotettavaa osapuolta. (Mayer ym. 1995.) Luottamus ihmisiin ja instituutioihin tekee elämästä ennustettavan ja hallittavan ja tuo mielekkyyttä elämään ajattelun suuntautuessa muualle kuin riskien ja uhkien ennakointiin (Harisalo \& Miettinen 2012, 24).

Luottamus voi olla henkilöiden välistä, mutta se voi olla myös systeemistä tai institutionaalista luottamusta, jolloin viitataan luottamukseen institutionaalisten ja sosiaalisten järjestelmien, kuten lakien, normien, verkostojen ja organisaatioiden, toimintaan. Institutionaalinen luottamus esimerkiksi edesauttaa henkilöiden välisen luottamuksen syntyä osapuolten vuorovaikutuksen alkuvaiheessa, jolloin osapuolet eivät välttämättä vielä tunne toisiaan. Institutionaalinen luottamus korostuu etenkin organisaatiokontekstissa, jossa se liittyy työnjakoon ja velvollisuuksiin pohjautuviin normatiivisiin sääntöihin sekä yhteisesti jaettuihin merkityksiin ja odotuksiin. Sitä siis tuotetaan organisaation sisällä. (Rousseau ym. 1998; Bachmann 2003; Sloyan \& Ludema 2010, 251.)

Henkilöiden, esimerkiksi johtajien ja työntekijöiden, välisen luottamuksen lisäksi voidaan siis puhua luottamuksesta organisaatioon. Tällöin on kyse luottamuksesta organisaation institutionaalisiin käytänteisiin, joita erityisesti strategisen tason johtajat kehittävät, kuten strategiaan ja visioon, organisaatiorakenteisiin ja toiminnan ohjaukseen sekä päätöksenteko- ja johtamisjärjestelmiin. Luottamus organisaatioon on eri asia kuin luottamus johtajiin henkilöinä. Johtajaan luottamisen on kui- tenkin havaittu vaikuttavan organisaatioon luottamiseen, sillä johtaja on myös organisaation edustaja. Esimerkiksi jos työntekijä ei luota lähijohtajaansa, se heikentää kuvaa koko organisaation luotettavuudesta. Koettu luottamus organisaatioon rakentuu siis laajalta pohjalta ja useiden eri toimijoiden kautta. (Gillespie \& Dietz 2009; Vanhala 2011, 19-36; Fulmer \& Gelfand 2012, 1208.)

Tärkeä luottamuksen sekä luottamuksellisen ilmapiirin syntyyn vaikuttava tekijä on toisen osapuolen luotettavuus, jonka osatekijöiden avulla luottamusta on mahdollista tarkastella empiirisesti. Kyse on sinällään kahdesta eri käsitteestä:luotettavuus on luotettavan henkilön tai tahon ominaisuus, ja luottamus on sitä mitä luottaja tekee.Vaikka joku olisi luotettava, häneen ei välttämättä luoteta. Luotettavuuden osatekijät kuitenkin korreloivat luottamuksen kanssa ollen luottamuksen osatekijöitä ja ennustaen sen syntyä. Luotettavuuden osatekijöitä on sovellettu henkilöiden välisen luottamuksen lisäksi organisaatioita kohtaan tunnettuun luottamukseen, jota ne myös rakentavat ja ennustavat. (Mayer ym. 1995; Dietz \& den Hartog 2006; Gillespie \& Dietz 2009; Fulmer \& Gelfand 2012,1174-1190.)

Luotettavuutta kuvaavissa eri indikaattoreissa toistuvia tekijöitä ovat kyvykkyys, ennustettavuus, hyväntahtoisuus ja rehellisyys. Kyvykkyys (ability) viittaa taitoihin ja tietoihin, eli siihen että luotettavalla taholla on tarvittavat tekniset kyvyt tai muut taidot, joilla tämä pystyy suoriutumaan tehtävistään. Organisaatioiden kohdalla kyvykkyys viittaa siihen, miten se pystyy saavuttamaan tavoitteensa tehokkaasti. Ennustettavuus (predictability) viittaa luotettavan 
tahon johdonmukaisuuteen ja säännöllisyyteen. Hyväntahtoisuus (benevolence) kuvastaa luotettavan tahon motiiveja ja henkilökohtaista asennetta sekä luottajan hyvinvoinnista huolehtimista. Rehellisyys (integrity) taas viittaa luottajan hyväksymissä periaatteissa pysymiseen pitäen sisällään rehellisyyden ja reilun kohtelun sekä tekopyhyyden (hypocrisy) välttämisen ja moraalisten periaatteiden noudattamisen. (Mayer ym. 1995; Dietz \& den Hartog 2006; Gillespie \& Dietz 2009.)

Luottamus eri toimijoiden välillä kehittyy kanssakäymisen, yhteistyön ja vuorovaikutuksen myötä osapuolien tunnistaessa ja tulkitessa näitä luotettavuuden elementtejä. Luottamus ei siis ole muuttumaton asia, vaan voi kasvaa tai heikentyä ajan myötä. (Rousseau ym. 1998; Harisalo \& Miettinen 2012, 29.) Johtajia sekä organisaatiota kohtaan tunnettua luottamusta rakentaviksi keinoiksi on nostettu esille muun muassa työntekijöiden osallistuminen päätöksentekoon, vastavuoroinen palaute, avoin kommunikaatioilmapiiri, työntekijöiden valtuuksien ja vastuiden lisääminen sekä reiluus ja oikeudenmukaisuus organisaatioiden toiminnassa. Myös lähijohdon ja etenkin organisaation ylimmän johdon antama tuki, joka tuo työntekijöille kokemuksen siitä, että organisaatio välittää heidän hyvinvoinnistaan ja arvostaa heitä, luo luottamusta. (Nyhan 2000; Dirks \& Ferrin 2002, 622-623; Albrecht \& Travaglione 2003; Connell ym. 2003.)

Etenkin organisaatiomuutoksissa luottamuksella on suuri rooli, sillä muutokset tuottavat työntekijöissä epävarmuutta tehtäväkuvien ja professiorajojen mahdollisesti muuttuessa.
Tällöin he tarkkailevat etenkin strategisen johdon aikeita saattaen tehdä niistä liioittelevia ja luottamusta heikentäviä tulkintoja. Näin luottamuksen kokemiseen vaikuttaa eri signaalien, kuten strategiadokumenttien, toimintapolitiikkojen tai erilaisten muutostapahtumien tulkinta. (Sorensen 2011.) Muutoksissa siis korostuu Weickin (1995) sensemaking-viitekehyksen ${ }^{2}$ mukainen pyrkimys tapahtumien arviointiin ja merkityksien antamiseen muuttuneelle tilanteelle. Muutostilanteessa ihmiset arvioivat jatkuvasti, onko muutos hyödyllinen heille itselleen ja organisaatiolle, ja tämä määrittelee heidän tukensa muutokselle ja suostumuksensa uudenlaiseen yhteistyöhön. Ilman sensemaking-prosessia muutos ei voi edetä organisaatiossa laajemmin. (Sloyan \& Ludema 2010; Peltoniemi 2018.)

Sensemaking-prosessia taas ei voi olla ilman niin sanottua sensegiving-prosessia, joka on tarkoituksellista vaikuttamista muiden ajatuksiin uudenlaisen toiminnan saavuttamiseksi. Tässä organisaation johtajilla on suuri rooli, sillä ilman sensegiving-prosesseja työntekijöille ei synny ymmärrettävää kuvaa tavoitteista ja muutoksen syvemmästä merkityksestä. Nämä prosessit eivät onnistu ilman luottamusta. Organisaatioissa kaikilla toimijoilla ei voi olla yhtäläistä informaatiota tapahtumista ja asioista, eikä yhtäläisiä mahdollisuuksia saada tarvittavaa informaatiota. Luottamusta tarvitaan, jotta sensemaking palvelisi organisaatiota, sillä luottamus johtoon kompensoi informaation puutetta ja epävarmuutta vähentäen erilaisia olettamuksia ja tulkintoja. Ilman luottamusta työntekijät eivät kiinnitä huomiota siihen, mitä heille kerrotaan, vaikka johtajat kertoisivatkin heil- 
le kiistämättömiä faktoja. (Harisalo \& Stenvall 2004, 56-58; Sloyan \& Ludema 2010; Peltoniemi 2018.)

Ilman luottamusta työntekijät saattavat kokea organisaatiomuutoksen toisin kuin johtajat esittävät. Mutta vaikka organisaatioissa kaikilla toimijoilla ei voikaan olla täydellistä informaatiota tapahtumista ja asioista (Harisalo \& Stenvall 2004, 56-58), pyrkimys kattavaan tiedottamiseen silti kannattaa. Esimerkiksi laajoissa organisaatiomuutoksissa pyrkimys avoimuuteen sekä työntekijöiden laajoihin osallistumismahdollisuuksiin lieventävät muutosvastarintaa ja pelon sekä epävarmuuden tuntemuksia vaikuttaen positiivisesti luottamukseen. Etenkin työntekijöiden osallistumis- ja vaikuttamismahdollisuudet sekä heidän näkemystensä kuunteleminen ovat tärkeitä, sillä pelkkä yksisuuntainen tiedottaminen luo mahdollisuuden luottamusta heikentäville johdon viestien väärintulkinnoille. (Sloyan \& Ludema 2010; Sorensen 2011; Katsaros ym. 2014.)

\section{TutKIMUKSEN TOTEUTUS}

Tutkimus toteutettiin jokin aika sitten toimintansa aloittaneessa sosiaali- ja terveyspalvelujen kuntayhtymässä, jossa samaan organisaatioon oli yhdistetty usean kunnan perusterveydenhuolto, sosiaalipalvelut sekä erikoissairaanhoito. Tutkimuksen 61 haastateltua edustivat organisaation strategista, keski- ja lähijohtoa sekä työntekijöitä,ja he toimivat organisaation yleishallinnossa, perhe- ja sosiaalipalveluissa, perusterveydenhuollossa ja vanhuspalveluissa. Näkökulma ei ollut pelkästään asiakasrajapinnassa toimivien työntekijöiden kokemuksissa, sillä johtajatkin ovat tulkittavissa organisaation palveluksessa olevaksi henkilöstöksi.

Haastattelut toteutettiin helmikuun 2017 ja tammikuun 2018 välisenä aikana yksilö-, pari- tai ryhmähaastatteluina. Haastattelijoina toimi tutkimusryhmän edustajia Itä-Suomen yliopistosta ja THL:lta, ja kysymykset pohjautuivat yhteiseen teemahaastattelurunkoon. Haastatteluteemat käsittelivät muun muassa organisaation rakenteellisia ja toiminnallisia muutoksia, niiden vaikutuksia työntekijöihin ja asiakkaisiin sekä ammattirakenteisiin, muutosten vaikutuksia osaamistarpeisiin, työntekijöiden roolia muutoksissa, vaikutusmahdollisuuksia organisaation toimintaan, omalle työlle saatavaa tukea sekä kokemuksia organisaation johtamisesta. Haastattelut tallennettiin digitaalisesti ja litteroitiin sanatarkasti, aineistoa kertyi 567 sivua (fontti Times New Roman 12, riviväli yksi).

Luottamusta päätettiin tarkastella luotettavuuden osatekijöiden avulla luotettavuuden rakentaessa luottamusta sekä luottamuksellista ilmapiiriä organisaatiossa. Näiden osatekijöiden avulla on siis mahdollista tehdä luottamukseen liittyviä päätelmiä. (Esim. Fulmer \& Gelfand 2012.) Taulukkoon 1 on tiivistetty erilaisia luotettavuuden osatekijöitä. 
Taulukko 1. Johtajien ja organisaation luotettavuuden osatekijöitä (Mayer ym. 1995; Nyhan 2000; Dirks \& Ferrin 2002, 622-623; Albrecht \& Travaglione 2003; Connell ym. 2003; Dietz \& den Hartog 2006; Gillespie \& Dietz 2009; Fulmer \& Gelfand 2012).

\begin{tabular}{|c|c|}
\hline Johtajien luotettavuuden osatekijöitä: & $\begin{array}{l}\text { Organisaation luotettavuuden } \\
\text { osatekijöitä: }\end{array}$ \\
\hline 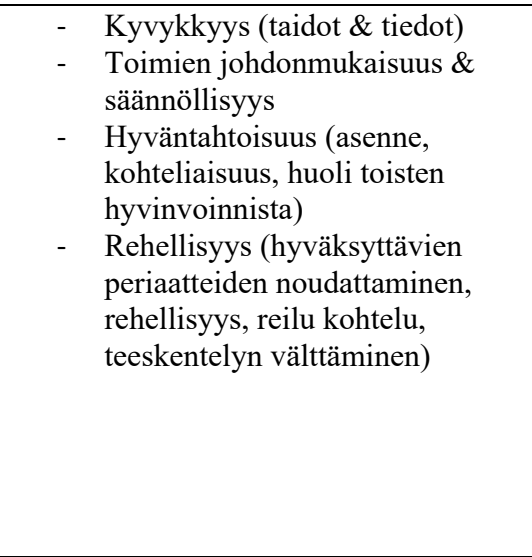 & $\begin{array}{ll}\text { - } & \text { Tavoitteiden saavuttaminen } \\
& \text { tehokkaasti } \\
\text { - } & \text { Toimien johdonmukaisuus ja } \\
& \text { säännöllisyys } \\
\text { - } & \text { Organisaation antama arvostus ja } \\
& \text { kokemukset hyvinvoinnista } \\
& \text { välittämisestä } \\
\text { - } & \text { Työntekijöiden valtuuksien ja } \\
& \text { vastuun lisääminen } \\
\text { - } & \text { Avoin kommunikaatioilmapiiri } \\
\text { - } & \text { Työntekijöiden osallistaminen ja } \\
& \text { palautekäytännöt } \\
\text { - } & \text { Kokemukset organisaation } \\
& \text { reiluudesta ja } \\
& \text { oikeudenmukaisuudesta }\end{array}$ \\
\hline
\end{tabular}

Aineiston analyysi toteutettiin teoriaohjaavan sisällönanalyysin avulla. Tässä abduktiivisessa sisällönanalyysin muodossa analyysi etenee aineiston ehdoilla. Aineistolähtöiseen sisällönanalyysiin verrattuna teoreettiset käsitteet tuodaan esille kuitenkin ilmiöstä jo tiedettynä eli niitä ei luoda aineistosta käsin. Aiempi tieto siis ohjaa tai auttaa analyysiä siten, että se avaa uusia näkökulmia tutkittavaan aiheeseen. (Tuomi \& Sarajärvi 2018.) Käytännössä analyysi eteni lähilukemalla aineistoa luottamukseen liittyvän esitiedon ohjaamana ja etsimällä luottamusnäkökulman ohjaamana kohtia, joissa haastatellut puhuivat organisaatiossa muuttuneista asioista. Näin aineiston pohjalta muodostettiin luokkia, jotka yhdistettiin tutkimuskysymysten mukaisten pääteemojen alle. Lopuksi tutkimuskirjallisuuden avulla tarkasteltiin, miten muutokset vaikutti- vat johtajien ja organisaation kokemiseen luotettavina.

\section{LUOTTAMUS JOHTAJIIN}

Kuntayhtymän muodostaminen ja käynnistyminen tarkoittivat siihen siirtyvälle henkilöstölle uudenlaisen organisaatiorakenteen omaksumista. Organisaatiorakenteessa esimerkiksi osa keskijohdosta toimi päällikön nimikkeellä ja osa johtajan nimikkeellä kehittämistehtävissä ilman varsinaisia johtamisvastuita. Johtamisjärjestelmä oli haastattelujen perusteella muuttunut muutenkin, esimerkiksi kuntien sosiaali- ja terveyspalvelujen johtajia oli siirtynyt uudenlaisiin tehtäviin, ja lähijohtajille oli tarkoitus antaa enemmän päätäntävaltaa. Näihin muutoksiin totuttelu tuotti ongelmia. Esimerkiksi jako päällikköihin ja johtajiin toi epä- 
selvyyksiä siitä, kuka on vastuussa mistäkin ja keneltä tiettyjä asioita pitäisi kysyä. Samoin uusiin tehtäviin siirtyneillä keski- ja lähijohtajilla oli epäselvyyksiä päätösvaltuuksistaan. Jotkut haastatellut mainitsivat, että kuntaorganisaatiossa heillä oli ollut laajemmat valtuudet, kun taas uudessa organisaatiossa he joutuivat varmistelemaan mistä saa päättää ja mistä ei. Tämän olivat työntekijätkin huomanneet:

”---omalla lähiesimiehellä on vähemmän minusta vaikutusvaltaa tällä hetkellä ku ajatellaan aikaa ennen [kuntayhtymää] niin omalla esimiehellä oli minusta enemmän päatöksentekovaltaa ja asiat hoitui paljo jouhevammin. Ja ne vei lyhyen aikaa." $\left(\mathrm{TT}^{3}\right)$

Myös työntekijät kokivat organisaatiorakenteen vaikeasti hahmotettavana, ja useiden erilaisten johtajien tehtäviä pidettiin epäselvinä. Kaiken kaikkiaan haastatteluissa tuli esille, että epäselvyydet johtamisrakenteissa ja -vastuissa näyttäytyivät muun muassa päätöksenteon hidasteluna, tiedonkulun puutteina sekä väärinymmärryksinä, jotka heikensivät johtajien kokemista luotettavana. Kuten tutkimuskirjallisuudesta (esim. Dietz \& den Hartog 2006) tulee ilmi, johtajien kyvykkyys sekä heidän toimiensa johdonmukaisuus ja ennakoitavuus rakentavat luotettavuutta. Näiden tekijöiden arviointi vaikeutui muutoksien myötä.

Luotettavuuden arviointiin ja luottamuksen rakentumiseen vaikuttivat myös johtajien toimenkuvien muutokset. Johtajilta saatu tuki on osoitus hyväntahtoisuudesta, ja tuen onkin todettu lisäävän johtajien luotettavuutta ja tätä kautta luottamusta (esim. Mayer
1995; Connell ym. 2003). Uudessa organisaatiossa etenkin monien lähijohtajien toimenkuva oli laajentunut erilaisten kehittämis- ja hallinnollisten tehtävien suuntaan, jolloin aikaa meni paljon erilaisten yhteistyöverkostojen luomiseen, suunnitteluun ja kokouksiin. Jotkut haastatellut kokivat tämän vievän aikaa työntekijöiden tukemiselta muutostilanteessa. Eräässä haastattelussa tuotiin esille, että joskus on vain jätettävä osa tehtävistä hoitamatta, jotta ehtisi huomioida työntekijät:

'H1: --- Että siinä on melkein aina et sä et missään kohdassa ke-, ehdi hoitamaan niitä kaikkia silleen, tasasen hyvin et sun pitää antaa jonkun kupin vähän rypsähtää, jotta.. H2: Aina joku on rempallaan.

H1: Tehdä valinta, että minkä palan otat siitä, ja että itsellä on ainakin hyvin vahvasti ollu se että on pakko valita se että seisoo niitten työntekijöitten tukena, koska sitten jos ne ei jaksa, niin sitten se...

H2: Korttitalo romahtaa." (LJ)

Eräässä haastattelussa tuotiin esille, että pienemmässä kuntaorganisaatiossa työntekijät saattoivat olla yhteyksissä kunnanjohtajankin kanssa, mutta organisaatiomuutoksen myötä hierarkkisuuden koettiin kasvaneen, koska yhteys ylempiin tahoihin tapahtui vain lähijohtajan kautta. Työntekijähaastatellut kokivat, että juuri lähijohtaja on heille läheisin ja heitä kuunteleva taho, kun taas omaa keskijohtoa ei kovinkaan usein nähty tai edes tiedetty; he saattoivat näkyä vain sähköpostien lähettäjinä. Lähijohtoa ylempien johtajien luotettavuuden arviointi oli siis vaikeutunut, ja heidän koettiin jopa vieraantuneen käytännön työstä: 
”---tämä nykyinen [lähi]johtaja on kyllä se jonka kanssa kaikkein parhaiten ollaan pärjätty, et hän tietää kuitenkin nämä meidän olosuhteet täallä. Joskus tulee sellainen tunne että ne ihan siellä ylhäallä hallinnossa alkaa hiukan olla vieraantuneita tästä käytännöstä.” (TT)

Lähijohtaja siis koettiin henkilönä, jolle työntekijöiden näkemyksiä voitiin esittää, mutta työntekijähaastatteluissa suhtauduttiin epäilevästi näkemysten etenemiseen lähijohtotasolta ylöspäin. Eräs lähijohtaja toi kokemuksenaan esille sen, ettei heitäkään tunnuta kuultavan:

"en itsekään tietenkään koe olevani kauheen osallinen tässä kehittämistyössä esimiehenä niin eihän ne työntekijätkään sillon oo että miten tätä [kuntayhtymää] rakennetaan." (LJ)

Johtajia oli uudessa organisaatiossa siirtynyt myös sellaisiin tehtäviin, joiden substanssista heillä ei ollut aiempaa kokemusta, eikä kaikilla lähijohtajilla ollut välttämättä aiempaa johtamiskokemusta. Lähijohtajahaastatteluissa tuli esille, että he tiedostivat roolinsa tärkeyden muutoksen eteenpäin viemisessä, mutta kokivat tarvitsevansa itse tukea ja työkaluja työntekijöidensä tukemiseen. Keskijohdon haastatteluissa kyllä pidettiin tärkeinä uusia esimiespalavereita, joiden myötä eri alueiden lähijohtajien oli mahdollista saada vertaistukea toisiltaan. Lähijohtajatkin siis tarvitsevat arvostusta ja tukea organisaation sekä omien esimiestensä suunnalta, jotta jaksaisivat ja pystyisivät olemaan työntekijöiden tukena edistäen tätä kautta itseensä sekä organisaatioon kohdistuvaa luottamusta.
Muuttuneeseen organisaatiorakenteeseen liittyi kasvanut hajautuneisuus, jossa jonkin yksikön työntekijät saattoivat toimia eri paikkakunnilla kuin johtajansa. Haastatteluissa tuli esille, että työntekijät kuitenkin toivoivat lähijohtajiensa olevan fyysisesti lähellä. Kaukana johtajasta työskentelevät kokivat esimerkiksi olevansa epätasa-arvoisemmassa asemassa, kun eivät pystyneet esittämään näkemyksiään vaikkapa kahvipöydässä. Organisaation ylin johto koettiin myös rakenteellisesti ja henkisesti aiempaa etäisemmäksi, mikä osin juontuu organisaatiokoon kasvamisesta ja maantieteellisesti etäällä toisistaan olevien toimipisteiden yhdistämisestä. Ylemmän johdon etäisyys korostui etenkin työntekijöiden haastatteluissa, mutta lähijohtajienkin haastatteluissa esiintyi näkemyksiä ylemmän johdon olemisesta jo liian etäällä työntekijä-/ asiakasrajapinnasta. On siis luultavaa, että maantieteellinen etäisyys vaikeuttaa johtajien luotettavuuden arviointia ja johtajien mahdollisuuksia tukea työntekijöitään.

Johtajien keskuudessa luottamusta heitä ylempiin johtajiin heikensi ristiriitainen palaute tehdyistä päätöksistä. Johtajille oli annettu valtuudet tehdä päätöksiä itse etenkin silloin, jos ohjeistus ei anna selvää vastausta. Kuitenkin keski- ja lähijohdon haastatteluissa mainittiin, että päätöksen tekemisen jälkeen oli toisinaan tullut moitteita siitä, ettei päätöstä olisi saanut tehdä, vaan olisi pitänyt kysyä neuvoa ylempää. Eräässä lähijohdon haastattelussa puhuttiin "teflonpinnan" kehittämisestä, jotteivat mahdolliset moitteet ja niistä ahdistuminen pysäyttäisi omaa työskentelyä. Eräs strategisen johdon haastateltu antoi osuvan kommentin: "Ja palautekulttuurin pitäisi 
muuttua. Me pelätään hirveesti että me tehdään väärin tai sääntöjen vastaisesti, ihan niinkun se ois maailmanloppu." Pyrkimykset lisätä johtajien valtaa ja vastuita sekä saadut moitteet siitä, että valtaa on menty käyttämään, heikensivät luottamuksen kokemusta.

Lähijohtajien ja työntekijöiden haastatteluissa nousi esille toiveita arvostavasta ja rehellisestä puheesta. Haastatellut toivat esille, että organisaatiossa on töissä vahvasti koulutettua henkilöstöä, joka kyllä ymmärtää ja arvostaa älykästä puhetta, jossa erilaiset vaikeudet tuotaisiin suoraan esille. Asioiden kaunistelua ei siis arvostettu. Joissain työntekijöiden haastatteluissa tuli myös esille tylyksi koettu ylempien johtajien kommunikaatiotyyli. Haastatellut tiedostivat, että johtajan pitää olla jämäkkä, mutta he kaipasivat, että asioita ajetaan arvostavalla eikä ylimielisellä tavalla. Kohtelias ja arvostava kommunikointi kuitenkin on keino osoittaa, että työntekijöitä arvostetaan; kohteliaisuus onkin yhdistetty johtajia kohtaan tunnettuun luottamukseen (Fulmer \& Gelfand 2012, 1187).

\section{LUOTTAMUS ORGANISAATIOON}

Uuden organisaation synty tarkoitti henkilöstölle muun muassa uudenlaisten toimintatapojen opettelua, vanhoista ajattelumalleista luopumista, erilaisten kuntakohtaisten ja ammatillisten kulttuureiden törmäämistä sekä epätietoisuutta muutosmyllerryksen keskellä. Tämä kaikki tarkoitti sensemaking- ja sensegiving-prosessien roolien sekä luottamuksen merkityksen korostumista. Haastatteluissa tuli esille, että muutokset eivät koetelleet kaikkia alueita ja toimialoja samoilla tavoilla. Mutta siellä missä muutosta oli tapahtunut, se todella herätti huolta:

"---tää organisaation muutos on herättäny totta kai pelkoja ja huolta ja, ehkä nyt työpaikan menettämisen pelkoa meillä ei kellään oo ollu mutta se että muuttuuko minun tehtävänkuva ja minkä verran muuttuu, ja kun usean kunnan alueella toimitaan, joudunko toimimaan joka kunnassa vai onko mulla se joku kotikunta, kotokunta missä toimin." (LJ)

Johtajien haastatteluissa tulikin esille henkilöstön vaikeudet luopua kuntakeskeisestä ajattelusta. Esimerkiksi keskijohdon haastatteluissa tuli esille, että kuntarajat olivat joissain tapauksissa vielä hyvin tiukkoja, ja että tulee viemään paljon aikaa luoda ja omaksua koko kuntayhtymän yhteinen toimintakulttuuri alueen yhteisistä potilaista sekä asiakkaista:

”---että kun tulee kunnasta, riitti se että katto kunnan asioita. Nyt pitää kattoo koko aluetta. Ja välillä se on helpompaa, välillä se on vähän vaikeempaa. Ja sitte se että, että kun ennen me pystyttiin ajattelemaan et se meidän tapa tehdä on oikee, ja nyt pitäs löytää sit se konsensus.” (KJ)

Uuden organisaation myötä henkilöstön olisi alettava toimia joidenkin haastateltujen sanoin "kuntayhtymän mallin mukaan”. Tämä herätti huolestuneisuutta siitä, miten käy hyviksi koetuille aiemmille toimintatavoille. Keskijohdon haastatteluissa mainittiin, että mikäli aiemmat kunnissa vallinneet hyvät käytännöt sopivat kuntayhtymän linjauksiin, niistä ei olisi syytä luopua. Kuitenkin oli kokemuksia siitä, että uudet toimintatavat olivat huonompia 
kuin aiemmat, minkä arveltiin herättävän eettisiä ristiriitoja työntekijöissä:

"---työntekijäthän haluaa tehdä laadullisesti hyvää työtä. He on ammatti-ihmisiä. Ja sitten he joutuu sitä omaa vaatimustasoa laskemaan, ja kuka minkäkin verran pystyy et se on jokaisen omassa, etiikassa sitten kuinka paljon sitä pystyy.” (LJ)

Eräs lähijohtaja totesi, että joskus on luovuttava jossakin kunnassa vallinneesta todella hyvästäkin käytännöstä, jotta resurssien tasauksen nimissä "kaikkialla olisi hyvä”. Hän kuitenkin toi esille, että tämänkaltaisissa menettelyissä pitää perustella minkä takia näin tehdään. Tämä aihepiiri kuvastaa muun muassa sensemaking- ja sensegiving-prosesseja, joissa työntekijät arvioivat, onko muutos hyödyllinen heidän itsensä lisäksi myös organisaatiolle ja sen asiakkaille, ja johtajat yrittävät tuoda tätä esille (esim. Sloyan \& Ludema 2010; Peltoniemi 2018). Organisaation luotettavuuden ja luottamuksen näkökulmasta ei voi pitää hyvänä asiana, mikäli työntekijät eivät koe muutosta hyödyllisenä, tai mikäli muutosta ei perustella kattavasti.

Osa haastatelluista koki kuntayhtymän kehittämisvaiheen melko keskuskaupunki- ja erikoissairaanhoitokeskeiseksi.Toiveita kuitenkin oli siitä, että muutoksessa rakennettaisiin kuntayhtymän yhteistä linjaa koko alueen ja eri toimialojen yhteistyönä, eikä asioita vain tehtäisi keskuskaupungissa aiemmin luodun mallin mukaan. Yksipuolista ohjeistamista ei katsottu kovin hyvällä:

"---menee taas jälleen kerran siihen semmoseen tasapäistämiseen että niitten eri yhteisöiden erityisominaisundet, tuntuu et jotenkin ne katoaa, häviää tähän isoon organisaatioon, tai niitä ei huomioida." (TT)

Myös terveydenhuolto- ja etenkin erikoissairaanhoitokeskeisyys sai haastatelluilta kritiikkiä. Erikoissairaanhoitoa arvosteltiin esimerkiksi siitä, etteivät sen edustajat ymmärtäneet uuden kuntayhtymän taloudellisia realiteetteja ja säästöpaineita. Useampikin haastatelluista totesi, että erikoissairaanhoidossa oli totuttu aina tarvittaessa kunnista saatavaan lisärahaan:

"[erikoissairaanhoidon puolella] ei millonkaan tarvinnut oikeastaan hirveesti sitä taloutta ajatella. Rahahan tuli, niihin palveluihin mitä tarvittiin, eikä tarvinnut edes hirveesti miettiä että mistä pitää säästää tai vähentää." (LJ)

Keskijohdon haastatteluissa tuli esille, että erilaisia organisaation yhteisiä lomakkeita oli luotu vain terveydenhuollon kontekstiin, jolloin sosiaalitoimen erityispiirteet olivat jääneet huomiotta. Myös eräs työntekijähaastateltu oli huolissaan siitä, että organisaation strateginen johtaminen näytti kääntyvän terveydenhuoltopainotteiseksi. Yleisesti haastateltujen toiveissa oli, että ajan myötä tällaisesta siiloajattelusta päästäisiin eri alojen yhteistoiminnan ja -kehittämisen suuntaan. Tässäkin ilmiössä tulee esille sensemaking-prosessit, joissa kokemukset epätasapainoisesta kehittämisestä heikentävät mielikuvia organisaation tasapuolisuudesta sekä muutoksen tarkoitusperistä ja rapauttavat tätä kautta luottamusta organisaatiota kohtaan.

Etenkin keski- ja lähijohdon haastatteluissa puhuttiin paljon jatkuvasti muuttuvista ohjeistuksista esimerkiksi 
henkilöstöhallintoon, toimivaltuuksiin tai asiakkaiden hoitopolkuihin liittyen. Haastatellut näkivät, että ohjeistuksien muuttuminen on organisaation käynnistysvaihetta elettäessä ymmärrettävää, mutta niiden vaihtuminen monta kertaa hyvin lyhyessä ajassa koettiin rasittavaksi:

”H1: Tänään saatiin ohjeistus. Joku sen muntti iltapäivällä ja seuraava tyrmäsi vielä seuraavana päivänä tai vielä seuraavan viikon aikana et joo et on, liian hätäsesti ohjeistettiin ja eri tahon kautta.

H3: Sehän aiheutti sen että, nyt ei uskota mihinkä̈n ohjeeseen tällä hetkellä.” (KJ)

Muuttuvien ohjeistuksien myötä sähköpostien ja omaksuttavan tiedon määrä kasvoi melkoisesti, mikä vei aikaa muilta tehtäviltä. Ohjeistuksien soveltamisessa oli keskijohdon haastateltujen mukaan jätetty paljon harkinnanvaraa lähijohtajille, mikä liittyi lähijohdon roolin ja vastuiden vahvistamiseen. Tämä tuotti toisaalta ongelmia sen osalta, että eri lähijohtajien päätökset ja tulkinnat ohjeistuksista poikkesivat toisistaan heikentäen organisaation tasapuolisuuden kokemuksia. Työntekijähaastatteluissa mainittiin jopa koomisia piirteitä saanut epäjohdonmukaisuus joistain päätöksistä, jotka oli kumottu seuraavina päivinä. Eri tahoilta tullut ristiriitainen ja lyhyen ajan kuluessa muuttuva tieto oli heikentänyt luottamusta organisaation ja johtajien sanomisiin.

Haastatellut kokivat uuden organisaation avoimuuden heikoksi. Työntekijät kaipasivat enemmän tietoa nykytilanteesta ja tulevaisuuden suunnasta ja kokivat epävarmuuden vaikuttavan siihen, miten asioista pystyy kerto- maan potilaille tai asiakkaille. Tiedottaminen koettiin ylhäältäpäin tuleviksi käskyiksi ilman kunnon perusteluja tai avointa keskustelua. Samoin lähijohtajahaastatteluissa tuli esille, että esimerkiksi ohjeistuksia tai jopa tietoja organisaatiomuutoksista tuli yhtäkkiä "puun takaa" ilman tietoa niiden valmistelusta. Asia koettiin harmillisena, etenkin kun tiedot saattoivat haastateltujen mukaan paljastua jo ennen päätöksiä ja synnyttää kaikenlaisia huhuja. Nämä seikat ovat ongelmallisia luottamusnäkökulmasta, sillä osallistava päätöksenteko ja avoin kommunikaatio vaikuttavat positiivisesti luottamukseen (esim. Nyhan 2000; Albrecht \& Travaglione 2003).

Monet työntekijähaastatellut toivoivatkin, että heillä olisi enemmän tilaisuuksia keskustella ylemmän johdon kanssa. Haastatellut keskijohdon edustajat ymmärsivät henkilöstön kuulemisen tärkeyden, mutta toivat esille aikapulan ja maantieteellisesti laajalla alueella sijaitsevan organisaation vaikeudet järjestää kokouksia, joihin kaikilla olisi mahdollisuus päästä. Uutta organisaatiota käynnistettäessä aika ei yksinkertaisesti riittänyt kaikkeen, joten asioita pyrittiin hoitamaan lähijohtajien kautta. Toisaalta haastatellut keskijohtajat toivat esille, että johtajan tärkein tehtävä on tehdä päätöksiä; jossakin vaiheessa on sanottava se "viimeinen sana" miten asiat tehdään. Johtajilla siis oli halua keskustelevampaan työotteeseen, mutta organisaatiorakenne, toimintakäytännöt ja muutosmyllerrys hankaloittivat asiaa vaikeuttaen näin sensegiving-prosesseja ja luottamuksen rakentamista.

Organisaatioluottamukseen vaikuttavat myös tukea ja sitoutumista osoittavat 
HRM-käytänteet (Six 2005; FulmerGelfand 2012, 1198-1200), kuten erilaiset tuki- ja koulutusmuodot, jotka voidaan nähdä työntekijöiden arvostamisena. Työntekijähaastatteluissa nousi esille, että ammatillista osaamista lisääviin koulutuksiin ei ollut rahaa käytettävissä samassa määrin kuin aiemmin kunnissa. Kuntayhtymän sisäisiin lyhyisiin koulutuksiin oli mahdollista päästä oman työn mahdollistamissa puitteissa, mutta pidemmät henkilökohtaiset koulutusmahdollisuudet olivat haastateltujen mielestä minimissä. Joissain tapauksissa koulutuksiin oli teoriassa ollut mahdollista päästä, mutta käytännössä sijaisten puute oli estänyt osallistumisen.

\section{YHTEENVETO JA POHDINTA}

Aineiston pohjalta voidaan todeta, että organisaatiomuutos vaikutti sekä johtajiin että organisaatioon kohdistuvaan luottamukseen. Ensimmäinen tutkimuskysymys käsitteli johtajiin kohdistuvaa luottamusta, joka oli pääasiallisesti heikentynyt rakenteellisten ja hallinnollisten muutosten myötä. Uuden johtamisjärjestelmän myötä työntekijöillä ja johtajillakin oli epäselvyyksiä siitä, mistä johtaja voi päättää, jolloin toimien johdonmukaisuuden arvioiminen heikentyi. Lähijohtajien vastuulle oli lisäksi siirtynyt uusia tehtäviä, mikä joidenkin kohdalla heikensi heidän mahdollisuuksiaan olla työntekijöiden tukena muutoksen keskellä - ellei lähijohtaja sitten päättänyt jättää muita tehtäviään hoitamatta. Organisaatiomuutos kuitenkin onnistuu paremmin, mikäli työntekijät kokevat saavansa johdolta tukea prosessin aikana. Tällöin korostuu lähijohtajien rooli, koska työntekijät näkevät heidät organisaation pääedustajina. (Katsaros ym. 2014, 37.)

Johtajiin kohdistuvan luottamuksen osalta on hyvä huomioida, että mikäli lähijohtaja vaihtuu muutoksen myötä, niin työntekijöillä menee jonkin verran aikaa arvioidessa hänen kyvykkyyttään. Lisäksi arviointi vaikeutuu, mikäli lähijohtajalla on erilainen koulutustausta kuin työntekijällä. Haastatteluissa olikin viitteitä siitä, että työntekijät edelleen arvostavat lähijohtajallaan samaa koulutustaustaa. Johtajien kyvykkyyden ja hyväntahtoisuuden arviointia vaikeutti myös organisaation mahdollinen hajautuneisuus, jolloin työntekijöillä ei välttämättä ollut säännöllistä kontaktia lähijohtajaansa. Tällöin korostuu institutionaalinen luottamus (Bachmann 2003), joka liittyy lähijohtajan viralliseen rooliin ja asemaan organisaatiossa, eikä niinkään hänen persoonaansa. Kuitenkin mikäli organisaatiorakenne sekä lähijohtajan rooli ovat muuttuneet ja päätösvastuut epäselviä, tilanne hankaloituu myös institutionaalisen luottamuksen näkökulmasta.

Toinen tutkimuskysymys koski luottamusta organisaatioon, mikä sekin kärsi muutoksen keskellä. Kokemukset keskuskaupunkivetoisesta ja terveydenhuoltokeskeisestä uudistuksesta ja toiminnan kehittämisestä synnyttivät eriarvoisuuden ja epäreiluuden kokemuksia. Taskisen (2005) mukaan erilaisten organisaatioiden yhdistäminen on herkkä henkilöstön epäoikeudenmukaisuuden kokemuksille, mikäli menettelytavoissa ja jakopäätöksissä tulee vaikutelma siitä, että yksilön tai jonkin ryhmän toiminta jätetään huomioimatta. Sosiaali- ja terveysaloja kuvastavat 
toisistaan eroavat ammatilliset kulttuurit, joiden törmääminen ja uuden kulttuurin synnyttäminen liittyvät oikeudenmukaisuuteen ja tasavertaisuuteen. Tähän liittyviä ongelmia voidaan vähentää johtamisella, kuten kiinnittämällä huomiota osallistumiseen ja vuorovaikutukseen. (Emt.)

Erilaisten kuntakohtaisten organisaatiokulttuureiden ja ammatillisten kulttuureiden yhteensovittamisessa ja uuden luomisessa menee kuitenkin aikaa. Sensemaking-prosessiin vaikuttavat myös yksilöiden, ryhmien ja organisaatioiden perinteet. Organisaatioiden yhdistämisissä organisaatiokulttuuria halutaan muuttaa jonkin tietyn organisaation mukaiseksi, tai sitten pyritään luomaan uutta organisaatiokulttuuria. Kummassakin tapauksessa henkilöstö kuitenkin kokee epävarmuutta ja on huolissaan tulevaisuudestaan. (Weick 1995, 124-127; Peltoniemi 2018, 15.) Haastatteluissa toivottiin, että uusien toimintatapojen pitäisi olla kuntayhtymässä yhteisesti laadittuja, eikä jonkin tietyn tahon dominoimia. Tämä seikka pitäisi osata ottaa huomioon, mikäli sosiaali- ja terveyspalveluja tullaan integroimaan suurempiin kokonaisuuksiin.

Haastatteluissa tuli esille myös viitteitä siitä, että työntekijät ovat kokeneet muutosten vieneen organisaation toimintaa ja heidän omia työtehtäviään negatiiviseen suuntaan. Tämä korostaa muutosviestinnän ja henkilöstön kuulemisen merkitystä. Sekä sensemakingprosessin että luottamuksen näkökulmista on tärkeää, että muutos koetaan henkilöstön keskuudessa tarkoituksenmukaiseksi ja hyväksyttäväksi sekä työntekijöille itselleen että organisaatiolle ja sen asiakkaille. Johtajien olisi tuotava selkeästi esille, miksi ehdotettu tai toteutettu muutos on tärkeä, ja mitä sen pitäisi kohentaa. (Sloyan \& Ludema 2010; Katsaros ym. 2014; Peltoniemi 2018.)

Työntekijöiden ja myös lähijohtajien haastatteluissa tuli kuitenkin esille, että ylimmän tason johtajat koettiin etäiseksi. Tällöin saattaa syntyä epäilyksiä tiedoista ja taidoista, joilla organisaation asioista päätetään ja tulevaisuutta suunnitellaan. Etenkin muuttuvat ohjeistukset ja niiden tulkinnanvaraisuus korostivat lähijohtajien päätäntävaltaa ja heikensivät näiden ohjeistusten laatijoiden uskottavuutta. Organisaation avoimuuden puute taas loi otollisen ilmapiirin erilaisten työmotivaatiota ja -ilmapiiriä rapauttavien huhujen syntymiselle. Heikko kommunikaatioilmapiiri myös heikensi sekä organisaation että yksittäisten johtajien luotettavuutta. Johtajien sensegiving-prosessit eivät siis saaneet työntekijöiden sensemaking-prosesseja toimimaan organisaatiota palvelevalla tavalla, mihin osasyynä oli riittämätön luottamus.

Nämä seikat korostavat viestinnän tärkeyttä. Avoin ja läpinäkyvä kommunikaatioilmapiiri on organisaatiota sekä ylintä johtoa kohtaan tunnetun luottamuksen merkittävä osatekijä, ja se lisää myös henkilöiden välistä luottamusta (Albrecht \& Travaglione 2003; Fulmer \& Gelfand 2012, 1185-1186). Lisäksi johtajien on oltava vakuuttavia, kehittäviä, henkeä ylläpitäviä ja toisia arvostavia ollakseen luotettavia. Rakenteelliset ratkaisut ja hallinnolliset tekniikat eivät vahvista luottamusta, jos niiden käyttöä ei tueta omalla käytöksellä. (Harisalo \& Miettinen 2012, 34.) Haastatteluissa tuli esille, että johtajien tehtävä on joh- 
taa ja tehdä päätöksiä, ja se on tärkeää tehdä työntekijöitä arvostavalla ja kunnioittavalla tavalla. Esimerkiksi moitteiden antaminen siitä, että joku ei ole tulkinnut epäselviä ohjeistuksia oikein, vaikka organisaation tarkoitus on antaa lisää tulkintavaltaa, luo epäjohdonmukaisen kuvan sekä organisaatiosta että moitteita antavasta johtajasta.

Luottamus ei ole staattinen asia, vaan se muodostuu, heikkenee ja voi kehittyä uudelleen ajan myötä, aivan kuten sensemaking-prosessitkin etenevät ajan kanssa (Rousseau ym. 1998; Sloyan \& Ludema 2010). Organisaatiomuutoksen vaikeuksia voidaan lieventāä ja luotettavuutta parantaa kuuntelemalla työntekijöitä ja lähijohtoa, jalkautumalla heidän pariinsa sekä kertomalla asioista suoraan ja rehellisesti työntekijöiden asiantuntemus huomioiden. Työntekijöiden luottamus johtoon on avaintekijä yksilön ja organisaation tehokkuuden ylläpitämisessä muutosprosesseissa, joten asiaan on tärkeää kiinnittää huomiota. Esimerkiksi yksi muutosvastarintaa tuottava tekijä on työntekijöiden epävarmuus sekä tuntemattoman pelko, jolloin tehokkaiden palautekäytäntöjen merkitys korostuu. (Katsaros ym. 2014.)

Haastatteluissa tuli esille, että organisaatiomuutoksen oloissa keskijohdolla ei aina ole mahdollisuuksia päästä keskustelemaan työntekijöiden kanssa, vaikka halua löytyisikin. Tämä korostaa lähijohtajien roolia entisestään. Vaikka suurissa organisaatiomuutoksissa ylempi strateginen johto on tärkeässä roolissa symbolisena toimijana (Sorensen ym. 2011), niin käytännön toimijana juuri lähijohtaja on keskeinen työntekijöiden tukena, osallistajana sekä strategisen johdon lähettämien viestien välittäjänä ja tulkitsijana. Lähijohtaja toimii eräänlaisena linssinä, jonka kautta työntekijä tulkitsee organisaatiota vaikuttaen organisaatiota kohtaan tunnettuun luottamukseen (Gillespie \& Dietz 2009, 131). Usein ongelmana vain on se, ettei lähijohdolla eikä välttämättä keskijohdollakaan ole tietoa, mitä muutosmyllerryksessä on tapahtumassa ja miksi.Tämä korostaa eri johtotasojen välisen vuorovaikutuksen $\mathrm{ja}$ viestinnän tärkeyttä ja myös johtajien keskinäistä luottamusta. Muutosprosessissa ei sovi unohtaa, että lähi- ja ylempienkin tasojen johtajat ovat organisaation henkilöstöä, joka tarvitsee tukea omilta johtajiltaan sekä organisaatiolta.

Viestinnän ja osallistamisen lisäksi työntekijöiden luottamusta organisaatiota kohtaan voidaan parantaa tukea ja sitoutumista osoittavilla HRM-käytänteillä (Six 2005; Fulmer-Gelfand 2012, 1198), kuten erilaisilla tuki- ja koulutusmuodoilla, joiden koettiin haastatteluissa pääasiallisesti heikentyneen. Työntekijähaastatteluissa esiintyi toiveita eri alueiden toimintakäytänteisiin sekä hyviin käytäntöihin tutustumisesta, ja keskijohdon haastatteluissa mainittiin lähijohtajille suunnatut tuki- ja verkostopalaverit. Tällaisten tilaisuuksien hyödyntäminen olisi hyvä keino osoittaa, että organisaatio välittää sekä työntekijöidensä että johtajiensa osaamisen kehittämisestä. Myös tulevissa muutoksissa varhainen koulutus ja tapahtuvista muutoksista tiedottaminen edesauttavat muutosten hyväksymistä (Katsaros ym. 2014). 
PäÄTÄNTÄ

Artikkelin tulokset pääosin vahvistavat aiempien tutkimuksien tuloksia johtajilta saatavan tuen sekä muutosviestinnän ja palautekäytäntöjen tärkeydestä. Yksi täydentävä havainto on lähi- ja keskijohdon roolien muutos. Organisaatiomuutoksen keskellä keskijohdossa toimivien henkilöiden aikapula vaikeuttaa vuorovaikutusta työntekijöiden kanssa heidän toiveistaan huolimatta, mikä korostaa lähijohtajan roolia. Toisaalta lähijohtajan mahdollisuudet olla työntekijöiden tukena ja luottamuksen rakentajana vaikeutuvat lähijohtajien toimenkuvien laajetessa. Näistä syistä olisi tärkeää, että työntekijät tuntisivat johtajien työn sisältöjä ja realiteetteja. Toinen kiinnostava havainto on työntekijöiden kokemukset siitä, että he joutuvat toisinaan tekemään organisaatiomuutoksen myötä laadullisesti huonompaa työtä kuntaorganisaatioihin verrattuna. Kolmas kiinnostava havainto, etenkin sosiaali- ja terveyspalvelujen integraation näkökulmasta, on kokemukset organisaatiomuutoksen toteuttamisesta tiettyjen toimialojen dominoimana. Tulevissa muutoksissa pitäisi siis kiinnittää entistä enemmän huomiota työntekijöiden kuuntelemiseen, muutosviestintään sekä tasapuolisempaan kehittämiseen.

Haastatteluaineisto antaa silti vain poikkileikkauksen tietyn hetkisestä tilanteesta ja on mahdollista, että haastatteluihin osallistuneiden näkemykset organisaatiomuutoksesta eivät edusta koko organisaation näkemyksiä. Eräs mahdollinen jatkotutkimusaihe olisi tehdä uusia haastatteluja noin 1,5 vuotta organisaatiomuutoksen jälkeen tarkastellen, ovatko luottamukseen liittyvät tekijät muuttuneet ajan myötä muutosprosessin edetessä. Esimerkiksi organisaation ulkopuolelta tuleva systeeminen luottamus (Bachmann 2003), kuten koulutusjärjestelmän tuoman ammattitaidon sekä työehtosopimusten vaikutukset, olisi hyvä huomioida mahdollisissa jatkotutkimuksissa. Lisäksi nyt on keskitytty luottamukseen johtajia ja organisaatiota kohtaan, mutta muutostilanteissa kollegoidenkin välinen luottamus saattaa vaikuttaa positiivisesti. Vaikka johtaja vaihtuisi, niin työtoverit saattavat pysyä samoina, jolloin heiltä voi saada vertaistukea ja yhdistävää kokemusta "samassa veneessä olemisesta". Tämä voi edesauttaa organisaatiomuutokseen sopeutumista, etenkin kun sensemaking-prosessit ovat sosiaalisia (Weick 1995). Toinen kiinnostava näkökulma on johtajien luottamus työntekijöihinsä, jota on tutkittu suhteellisen vähän (Fulmer \& Gelfand 2012, 1193). Muutostilanteissa esimerkiksi lähijohtajien ja heidän työntekijöidensä vastavuoroinen luottamus toisiinsa saattaa helpottaa johtajan työtä.

Analyysin tuloksilla on merkitystä tutkimuksen lisäksi käytännön toimijoille. Voidaan olettaa, että sosiaali- ja terveyspalveluja tullaan integroimaan tulevaisuudessa aiempaa suuremmiksi kokonaisuuksiksi. Tällaiset siirtymät tarkoittavat uudenlaisten organisaatiorakenteiden luomista ja työntekijöiden siirtymistä niihin. Yhdistämisprosessin alkuvaihe on tärkeä luottamuksen synnylle vaikuttaen ratkaisevasti toiminnan sujuvuuteen myöhemmin (Taskinen 2005, 195). Siksi aiemmista vastaavista muutoksista on hyödyllistä ottaa oppia, ja valmistautua asioihin, joihin saatetaan törmätä luotaessa uusia sote-orga- 
nisaatioita, joissa erilaiset organisaatioja ammatilliset kulttuurit kohtaavat.

\section{VIITTEET}

1 Artikkeli on osa Strategisen tutkimuksen neuvoston rahoittamaa vuosina 2016-2019 toiminutta "COPE - Osaavan työvoiman varmistaminen sosiaali- ja terveydenhuollon murroksessa" -hanketta, joka jakautui viiteen eri osahankkeeseen. Artikkelin kirjoittajat edustavat Itä-Suomen yliopiston osahanketta "Hallinto ja johtaminen" sekä Terveyden ja hyvinvoinnin laitoksen osahanketta "Muuttuva työ".

2 Sensemakingia ja sensegivingiä on vaikea suomentaa. Esimerkkejä käännöksistä ovat merkityksen luonti sekä anto, merkityksellistäminen sekä järjellistäminen, mutta ne eivät sisällytä kaikkea mitä englanniksi sensemakingiin ajatellaan sisältyvän. (Peltoniemi 2018, 66.) Tässä artikkelissa käytetään näin ollen englanninkielisiä termejä.

3 Anonymiteetin turvaamiseksi ilmoitetaan vain, minkä tason haastattelusta sitaatti on. $\mathrm{SJ}=$ strategisen tason johto, $\mathrm{KJ}=$ keskijohto, LJ = lähijohto, $\mathrm{TT}=$ työntekijä.

\section{KirjallisuUs}

Albrecht, Simon \& Travaglione, Anthony (2003) Trust in public-sector senior management. International Journal of Human Resource Management 14 (1), 76-92. https://doi. org/10.1080/09585190210158529

Bachmann, Reinhard (2003) Trust and power as means of coordinating the internal relations of the organization: a conceptual framework. Teoksessa Bart Nooteboom \& Frédérique Six (toim.) The trust process in organizations. Northampton: Edward Elgar, 58-74. https://doi. org/10.4337/9781843767350.00010

Connell, Julia \& Ferres, Natalia \& Travaglione, Tony (2003) Engendering trust in manager-subordinate relationships - Predictors and outcomes. Personnel
Review 32 (5), 569-587. https://doi. org/10.1108/00483480310488342

Connell N.A.D. \& Mannion, Russell (2006) Conceptualisations of trust in the organisational literature - Some indicators from a complementary perspective. Journal of Health Organization and Management 20 (5), 417-433. https://doi. org/10.1108/14777260610701795

Dietz, Graham \& den Hartog, Deanne (2006) Measuring trust inside organisations. Personnel Review 35 (5), 557-588. https://doi. org/10.1108/00483480610682299

Dirks, Kurt \& Ferrin, Donald (2002) Trust in Leadership: Meta-Analytic Findings and Implications for Research and Practice. Journal of Applied Psychology 87 (4), 611-628. https://doi. org/10.1037/0021-9010.87.4.611

Fulmer, Ashley \& Gelfand, Michele (2012) At What Level (and in Whom) We Trust: Trust Across Multiple Organizational Levels. Journal of Management 38 (4), 1167-1230. https://doi. org/10.1177/0149206312439327

Gillespie, Nicole \& Dietz, Graham (2009) Trust Repair after an Organization-Level Failure. The Academy of Management Review 34 (1), 127-145. https://doi. org/10.5465/amr.2009.35713319

Harisalo, Risto \& Stenvall, Jari (2004) Trust as Capital: The Foundation of Management. Teoksessa Maija-Leena Huotari \& Mirja Iivonen (toim.) Trust in Knowledge Management and Systems in Organizations. Hershey / London: Idea Group Publishing, 51-80. https:// doi.org/10.4018/978-1-59140-126-1. ch003

Harisalo, Risto \& Miettinen, Ensio (2012) Luottamus - Pääomien pääoma. Tampere: Tampere University Press.

Hiilamo, Heikki (2015) Yliopistot ja soteuudistus. Janus 23 (3), 245-246.

Hämäläinen, Sanna \& Tiirinki, Hanna \& Suhonen, Marjo (2014) Vastavuoroisen luottamuksen vahvistaminen terveydenhuollon muutosprosessissa lähijohtajien kokemana - psykologisen sopimuksen näkökulma. Sosiaalilääketieteellinen aikakauslehti 51,177-190.

Kangas, Heli (2017) Asiantuntijoiden välinen luottamus ja sosiaalinen työnjako 
julkisen terveydenhuollon organisaatioissa. Dissertations in Social Sciences and Business Studies No 146. Kuopio: UEF.

Katsaros, Kleanthis \& Tsirikas, Athanasios \& Bani, Sofia-Maria (2014) Exploring employees' perceptions, job-related attitudes and characteristics during a planned organizational change. International Journal of Business Science and Applied Management 9 (1), 36-50.

Kröger, Teppo (2017) Sosiaali- ja terveyspalvelujen reformaatio. Janus 25 (2), 160-165.

Mayer, Roger \& Davis, James \& Schoorman, David (1995) An Integrative Model of Organizational Trust. Academy of Management Review 20 (3), 709-734. https://doi.org/10.5465/ amr.1995.9508080335

Nyhan, Roland (2000) Changing the Paradigm - Trust and Its Role in Public Sector Organizations. American Review of Public Administration 30 (1), 87-109. https://doi. org $/ 10.1177 / 02750740022064560$

Peltoniemi, Jarmo (2018) Kaiken keskellä - Keskijohto strategisen muutoksen tekijänä ja kokijana. Jyväskylä studies in business and economics 190. Jyväskylä: JYU.

Rousseau, Denise \& Sitkin, Sim \& Burt, Ronald \& Camerer, Colin (1998) Introduction to Special Topic Forum: Not so Different after All: A Cross-Discipline View of Trust. The Academy of Management Review 23 (3), 393-404. https:// doi.org/10.5465/amr.1998.926617

Sinervo, Timo \& Pekkarinen, Laura \& Sankelo, Merja (2015) Työyhteisön innovatiivisuutta edistävät tekijät muutoksessa. Teoksessa Jaana Saarisilta \& Johanna Heikkilä (toim.) Yhdessä innovoimaan - osallistuva innovaatiotoiminta ja sen johtaminen sosiaali- ja terveysalan murroksessa. Helsinki:THL, 132-144.
Six, Frédérique (2005) The Trouble with Trust - The Dynamics of Interpersonal Trust Building. Cheltenham: Edward Elgar. https://doi. org/10.4337/9781845426873

Sloyan, Robert \& Ludema, James (2010) That's not how I see it: How trust in the organization, leadership, process and outcome influence individual responses to organizational change. Research in Organizational Change and Development 18, 233-277. https://doi.org/10.1108/ S0897-3016(2010)0000018011

Sorensen, Ole \& Hasle, Peter \& Pejtersen, Jan (2011) Trust relations in management of change. Scandinavian Journal of Management 27, 405-417. https://doi. org/10.1016/j.scaman.2011.08.003

Ruokamo, Helena \& Suhonen, Marjo \& Paasivaara, Leena (2012) Luottamus terveydenhuollon projekteissa johtajan tulkintana. Sosiaalilääketieteellinen aikakauslehti 49, 196-208.

Taskinen, Helena (2005) Oikeudenmukaisuus ja kulttuurien kohtaaminen sosiaali- ja terveysalojen organisaatioiden yhdistämisessä. Kuopio: Kuopion yliopisto.

Tuomi, Jouni \& Sarajärvi, Anneli (2018) Laadullinen tutkimus ja sisällönanalyysi. Helsinki: Kustannusosakeyhtiö Tammi.

Vanhala, Mika (2011) Impersonal trust within the organization: what, how and why? Acta Universitatis Lappeenrantaensis 445. Lappeenranta: LUT.

Weick, Karl E. (1995) Sensemaking in Organizations. Thousand Oaks: Sage Publications. 